\title{
MALLARMÉ'S INSTRUMENTS: THE PRODUCTION OF THE INDIVIDU-LIVRE
}

The teleology of the universe is directed towards the production of beauty. ${ }^{1}$

\begin{abstract}
Ainsi, l'œuvre esthétique fait bourgeonner l'univers, le prolonge, constituant un réseau d'œuvres, c'est-à-dire de réalités d'exception, rayonnantes, de points-clefs d'un univers à la fois humain et naturel. ${ }^{2}$
\end{abstract}

\section{Instrumental Poetry?}

In the humanities, the word 'instrument', and related terms such as 'instrumentality' and ‘instrumentalization', generally come with a host of negative associations, quickly leading towards ideas about reification and alienation. In literary studies, having an instrumental approach to literature and language is associated with treating language transitorily, overlooking - at your own peril, as deconstructive and psychoanalytic readers have repeatedly shown us - that language contains an excess; that it speaks us, as much as we speak it. Instrumentality is linked to dogmatic politics and conceptual naïveté - occasionally Jean-Paul Sartre's Qu'est-ce que la littérature? and its famous assertion that 'la fonction d'un écrivain est d'appeler un chat un chat' are given the dubious honor of illustrating this. ${ }^{3}$ On the other hand, it is commonly accepted that Mallarmé represents the antithesis of this simplistic

\footnotetext{
${ }^{1}$ Alfred North Whitehead, Adventures of Ideas (New York: The Free Press, 1967), p. 265.

${ }^{2}$ Gilbert Simondon, Du mode d'existence des objets techniques (Paris: Aubier, 2012), p. 254.

${ }^{3}$ Jean-Paul Sartre, Situations IX, 10 vols (Paris: Gallimard, 1972), p. 281.
} 
view of language and literature. Mallarmé, we are told, was a poet who forged his entire poetics on the basis of a distinction between an instrumental approach to language, which he called 'l'universel reportage' (OC2, 212), and a poetic vision which he hoped would come together in the form of a 'Livre [...] explication orphique de la Terre' (OC1: 788). ${ }^{4}$

Yet, we also know that one of Mallarmé's most famous Divagations was entitled Le Livre, instrument spirituel (1895), and that Sartre considered Mallarmé to be "notre plus grand poète', not least because '[s]on engagement me paraît aussi total que possible: social autant que poétique'. ${ }^{5}$ This idea of the book as a spiritual instrument seems to indicate that instrumentality was less irredeemable for Mallarmé than it has been for many of his modern and postmodern readers. Obviously, the term 'instrument' evokes music as well as technics, and some readers may argue that Mallarmé has in mind this musical sense of the word. That is correct - for instance, Le Livre, instrument spirituel describes reading as ' $[\mathrm{u}] \mathrm{n}$ solitaire tacite concert' (OC2: 226). However, as this article aims to demonstrate, Mallarmé does not operate with a strong distinction between the musical and the technical understanding of the word 'instrument'; and more generally, Mallarmé's view of literature can indeed be called 'instrumental'.

In 2010, Anna Arnar presented a comparable argument, affirming that Mallarmé's work was simultaneously 'wildly idealist and fundamentally pragmatic', ${ }^{6}$ and stating that his

\footnotetext{
${ }^{4}$ All quotations from Mallarmé refer to Stéphane Mallarmé, Euvres complètes I, ed. by Bertrand Marchal, Bibliothèque de La Pléiade, 2 vols (Paris: Gallimard, 1998), and; Stéphane Mallarmé, Euvres complètes II, ed. by Bertrand Marchal, Bibliothèque de La Pléiade, 2 vols (Paris: Gallimard, 2003). I will use the in-text abbreviations $O C 1$ and $O C 2$.

${ }^{5}$ Sartre, Situations IX, p. 14.

${ }^{6}$ Anna Arnar, The Book as Instrument: Stéphane Mallarmé, the Artist's Book, and the Transformation of Print Culture. (Chicago: Chicago University Press, 2010), p. 1.
} 
Notes en vue du Livre were 'pragmatic and speculative'. ${ }^{7}$ This article concurs with Arnar's insistence on these seemingly opposing adjectives, and not least with the importance of highlighting the pragmatic, practical dimension of Mallarmé's approach to literature. In order to understand this practical dimension, the idea of the instrument is key. In what follows, I shall take a complementary route to Arnar's in an attempt to explain how Mallarmé marries pragmatism and wild idealism. Arnar situates Mallarmé's work in French fin-de-siècle cultural history, considering his aesthetic in the context of the birth of the artist's book and contemporary ideas about reading and pedagogy. In her last chapter, she furthermore examines the influence of Mallarmé's work on selected twentieth-century avant-garde artists. This article will approach the idea of instrumentality with a view to thinking the importance that Mallarmé's work can have today, two decades into the twenty-first century. My argument will thus be concerned less with fin-de-siècle culture than with showing how Mallarmé's idea of the book as a spiritual instrument relies on an ecological conception of subjectivity that anticipates contemporary theorizations of the relations between human beings, technical processes, and the environment. In this reading, Mallarmé emerges as a thoroughly ecological writer, defiantly dreaming about how fiction can help to align humans and their environments.

To this end the article comprises three sections: the first analyzes Mallarmé's speculative theorizations of the book, the second examines the practices of writing and reading, and the final part draws on the philosophy of Gilbert Simondon to further conceptualize what Mallarmé means by 'instrument spirituel' and to investigate the understanding of subjectivity that sustains this view of the instrument. As we move along, Mallarmé's writings will be placed in the context of contemporary debates which problematize notions of 'anthropocentrism' and 'human exceptionalism'. These terms

\footnotetext{
${ }^{7}$ Arnar, The Book as Instrument, p. 274.
} 
sometimes generate confusion and scepticism (that can in turn be met by confusion and scepticism: why are these terms so provocative?). To prevent this contemporary vocabulary (which I am unwilling to relinquish) from getting in the way of the argument about Mallarmé's writings, I will consider the term 'anthropocentric' as modelled on the term 'egocentric'. Anthropocentrism constitutes a species-wide form of egocentrism. To say, as sceptics sometimes do, that humans are necessarily anthropocentric, or that critiquing anthropocentrism is itself an anthropocentric endeavour, would then be analogous to dismissing a critique of egocentrism with the argument that as individuals we must necessarily be egocentric, or that a critique of egocentricism is in itself a form of egocentrism. Mallarmé's work, on the other hand, is characterized by a willingness to imagine much more 'wildly', as Arnar put it. This will become evident as we turn to his speculative writings on the book.

\section{The Book-Event: Politics and Beauty}

One of Mallarmé's most famous (and wild) statements can be found in the interview he gave for Jules Huret's Enquête sur l'évolution littéraire (1891): 'le monde est fait pour aboutir à un beau livre' (OC2: 702). Four years later, Le Livre, instrument spirituel begins by referencing this remark, thereby inviting us to consider the article in relation to other aspects of Mallarmé's work. In what follows, I will accept this invitation and offer an intertextual reading of the first two paragraphs of Le Livre, instrument spirituel, setting aside the relation between 'le Livre' and newspapers that emerges as a key concern in later paragraphs. The aim is to draw out three connected strands in Mallarmé's theorizations of the book, which will form the foundation of the argument developed in the later parts of this article. I will examine the social role of the book, the beauty of the book, and introduce the complex issue of agency, asking who creates the book and whether a book can 'act'. 
Le Livre, instrument spirituel begins: 'Une proposition qui émane de moi — si, diversement, citée à mon éloge ou par blâme — je la revendique avec celles qui se presseront ici — sommaire veut, que tout, au monde, existe pour aboutir à un livre' (OC2: 224). Throughout the twentieth century, writers and critics have continued to cite the statement, either to appropriate it ('It is not everyday that the world arranges itself into a poem ${ }^{8}$ ) or to mock it. ${ }^{9}$ It has been linked to alchemistic traditions, to Victor Hugo, to Jules Michelet, and to Friedrich Nietzsche's idea about the aesthetic justification of existence. ${ }^{10}$ Contrary to what many readers, including Arnold Hauser, have suggested, the world as book is a social and ontological idea as much as an aesthetic one. More accurately, in Mallarmé's texts such distinctions fall away as art, social life and ontology become intimately linked.

\footnotetext{
${ }^{8}$ Wallace Stevens, Collected Poetry \& Prose (New York: The Library of America, 1997), p. 905.
}

${ }^{9}$ See Arnold Hauser's damning (and incorrect) description of Mallarmé: 'He lived in the vacuum of his intellectualism, completely cut off from ordinary practical life, and having almost no relationships at all with the world outside literature [...]. No one ever followed Flaubert's example more faithfully. "Tout, au monde, existe pour aboutir à un livre" - the master himself could not have put it more Flaubertishly. "À un livre”, Mallarmé says; but what results is, in fact, hardly a book. He spends his whole life writing, rewriting and correcting a dozen sonnets, two dozen shorter and about six larger poems, a dramatic scene and some theoretical fragments'. See Arnold Hauser, The Social History of Art, trans. by Stanley Godman, 4 vols (London: Routledge, 1989), IV, p. 186.

${ }^{10}$ See Friedrich Nietzsche, The Birth of Tragedy: Out of the Spirit of Music, trans. by Shaun Whiteside (London: Penguin Classics, 2003). 
Many passages in Mallarmé's work emphasize the socio-political function of the book. One of the best known is found in Sauvegarde (1895), where Mallarmé reminds his readers of the political importance of 'upholding' the book:

\begin{abstract}
À savoir que le rapport social et sa mesure momentanée qu'on la serre ou l'allonge, en vue de gouverner, étant une fiction, laquelle relève des belles-lettres — à cause de leur principe mystérieux ou poétique — le devoir de maintenir le livre s'impose dans l'intégrité (OC2: 272).
\end{abstract}

Here Mallarmé posits that the social bond is a matter of fiction. This obviously does not mean that the social bond is inessential, that it is 'just a fiction'. On the contrary, fiction, or 'le Livre', is presented as a model for social relations, a key component in the construction of the socio-political sphere. There are several complex reasons for this.

First, it is important to understand that the book, or fiction, on which social relations must be modeled has no ground other than itself. There is no transcendental power, no God to underwrite its value. As Mallarmé puts it in Le Livre, instrument spirituel: 'Le livre, expansion totale de la lettre, doit d'elle tirer, directement, une mobilité et spacieux, par correspondances, instituer un jeu, on ne sait, qui confirme la fiction' (OC2: 226). In La Musique et les lettres (1894), Mallarmé similarly explains that fiction is only fiction if it is sufficiently self-aware to realize that it is not grounded, and can be subjected to 'un démontage impie' (OC2: 67). This absence of ground is a good thing, because it allows readers to participate in the 'game' of constructing the fiction, making it as compelling as 
possible, and at times even creating fictions that surpass our own ability to explain them ('un jeu, on ne sait', as Mallarmé put it). ${ }^{11}$

To clarify these ideas, we can introduce a counter-example to Mallarmé's ungrounded, self-aware and politically progressive fictions: those pretentious fictions that forget their own 'ungroundedness', and instead present themselves as an incarnation of eternal truth. Mallarmé's most famous example here is Richard Wagner, an impressive artist who is no longer content to produce fictions, but instead sees himself, and expects others to see him, as the communicator of immutable truths. In 1885, Mallarmé writes about '[1]e dieu Richard Wagner' (OC1: 40), much as Nietzsche would mock Wagner as 'the ventriloquist of God' two years later. ${ }^{12}$

If we return to Mallarmé's opening statement about the world becoming book and read it intertextually, we can thus propose that it speaks about the production of a book which will be ungrounded, open to future rewritings, and therefore a model for how to establish social relations.

The second paragraph of Le Livre, instrument spirituel considers the aesthetics of the book, introducing the idea of beauty, and raising the question of agency (who does what, and how?):

Les qualités, requises en cet ouvrage, à coup sûr le génie, m'épouvantent un parmi les dénués: ne s'y arrêter et, admis le volume ne comporter aucun signataire, quel est-il:

${ }^{11}$ This reading largely refers to La Musique et les lettres. I am proceeding rapidly here, but the reading has been presented in greater detail by several other critics. See for instance Pierre Bourdieu, Les Règles de l'art (Paris: Éditions du Seuil, 1992), pp. 380-383.

${ }^{12}$ Friedrich Nietzsche, On the Genealogy of Morality, trans. by Maudemarie Clark and Alan J. Swensen (Indianapolis: Hackett Publishing Company, 1998), p. 72. 
l'hymne, harmonie et joie, comme pur ensemble groupé dans quelque circonstance fulgurante, des relations entre tout. L'homme chargé de voir divinement, en raison que le lien, à volonté, limpide, n'a d'expression qu'au parallélisme, devant son regard, de feuillets (OC2: 224).

Beginning with the question of aesthetics, the passage makes clear that the book-hymn must be harmonious and joyous - and that it should express, in an instant, the relations between everything ('des relations entre tout'). This points back to the earlier interview with Jules Huret, where Mallarmé presented his idea about the world as book while highlighting beauty: 'le monde est fait pour aboutir à un beau livre' (OC2: 702, emphasis added). In modern Mallarmé criticism, the idea of beauty has often been marginalized, with critics preferring to cite the formulation that opens Le Livre, instrument spirituel ('tout, au monde, existe pour aboutir à un livre' (OC2: 24)). This is not surprising, given that the interview was penned by Huret, whereas Le Livre, instrument spirituel was entirely from the hands of Mallarmé. However, as this second paragraph shows, the idea of beauty (hymn, harmony and joy) appears in both texts, and therefore must not be overlooked. What role does beauty play? The point of highlighting beauty is not to pull Mallarmé back to romanticism, but rather to emphasize that the ungrounded 'livre' must live up to certain standards in order for it to be of general interest. Beauty becomes a marker for this general interest; it links back to the social role of the book. Beauty, which also lingers in Mallarmé's formulation about the book being grounded in the 'belles-lettres' (emphasis added), guarantees that the fiction is more than private fancy. We can therefore say that Mallarmé anticipates Antonio Negri's view of beauty when the philosopher writes: 'The beautiful is an invention of singularity which circulates and reveals itself as common in the multiplicity of subjects who participate 
in the construction of the world'. ${ }^{13}$ Mallarmé and Negri share the idea that beauty 'proves' (to use a mallarméan term) that an artwork has general interest, that it brings the collective together. Negri stresses this activist dimension of beauty when he suggests that 'the beautiful is [...] an imagination that has become action. Art, in this sense, is multitude'. ${ }^{14}$ Mallarmé's activism - that of L'Action restreinte - plays out differently, but Negri's formulations should be allowed to resonate in our reading of Mallarmé, because they bring out the social dimension in his idea of the beautiful book.

If we look to Mallarmé's production more widely, we can trace how beauty acquires this activist role, and how Mallarmé too links beauty and multitude. In July 1863, the young, pre-Parnassian Mallarmé advocates a conservative ideal of eternal, transcendent beauty. At the time of a Polish uprising against Russia, he asks his friend Henri Cazalis: 'Henri, est-ce que l'homme qui a fait la Vénus de Milo n'est pas plus grand que celui qui sauve un peuple, et ne vaudrait-il pas mieux que la Pologne succombât que de voir cet éternel hymne de marbre à la Beauté brisé?' (OC1: 650). By 1876, this dichotomy between 'the people' and 'eternal beauty' has disappeared, and Mallarmé credits Édouard Manet with inventing 'a strange new beauty' (OC2: 464) that is in touch with a modern age in which 'the multitude demands to see with its own eyes' (OC2: 467). ${ }^{15}$ Mallarmé thereby offers a perfect

\footnotetext{
${ }^{13}$ Antonio Negri, Art \& Multitude, trans. by Ed Emery (Cambridge: Polity Press, 2011), p. xii.

${ }^{14}$ Ibid., p. xii.

15 'The Impressionists and Édouard Manet' was written for The Art Monthly Review
} (September 30,1876). Mallarmé wrote the text in French, and then oversaw and authorized the English translation. The original text has been lost, so I am citing the English version (OC2: 444-470). 
anticipation of Georges Bataille, who in 1955 also wrote about Manet as a crucial moment in the history of art: the inventor of a modern and democratic kind of beauty. ${ }^{16}$

Having seen that the social role of the book goes hand in hand with its beauty, let us turn to the complex question of agency. The second sentence in the paragraph from Le Livre, instrument spirituel quoted above introduces the figure of 'l'homme chargé de voir divinement'. Mallarmé furthermore suggests that 'voir divinement' is to observe the correlation between pages and universe, to bring the two together in such a way that the book and the universe allow each other to make sense, so that we can understand the 'relations entre tout'. This is what Bertrand Marchal calls reading as 'divination'. ${ }^{17}$ But who is able to perform this task? Who (or what) does the hiring suggested by 'chargé'? Where does the initiative lie in this assemblage of writer, reader, book and world?

Mallarmé begins by downplaying his own role. He suggests that the work needs a genius, and that he himself is simply 'un parmi les dénués'. He then proposes that the book can be without a single author. It is therefore tempting to conclude that 'l'homme chargé de voir divinement' refers to the reader; that we are all invited to play the role of the genius, when we work with these analogies between page and universe. That is not untrue, and some passages in his work very explicitly present this view. We have already seen that 'the multitude demands to see with its own eyes', and we can also think of the sentence that Dr. Bonniot (Mallarmé's son-in-law) placed as an epigraph to Igitur: 'ce conte s'adresse à l'Intélligence du lecteur qui met les choses en scène, elle-même' (OC1: 475). Roland Barthes gave one canonical expression of this idea when he proposed that 'toute la poétique de Mallarmé consiste à supprimer l'auteur au profit de l'écriture (ce qui est, on le verra, rendre

\footnotetext{
${ }^{16}$ See Georges Bataille, Manet (Geneva: Éditions d'art Albert Skira, 1994).

${ }^{17}$ Bertrand Marchal, La Religion de Mallarmé (Paris: José Corti, 1998), p. 500.
} 
sa place au lecteur)'. ${ }^{18}$ This allowed him to present Mallarmé as paving the way for the famous conclusion that 'la naissance du lecteur doit se payer de la mort de l'Auteur'. ${ }^{19}$

However, Barthes's insistence on the birth of the reader coming at the expense of the author (to reuse the economic vocabulary that Barthes deploys in both passages cited above) does not fully capture the complexity of Mallarmé's thoughts on this issue. First of all, Barthes seems too keen to transfer agency from writer to reader. He reads Mallarmé's poetics as an illustration of the dialectic between master and slave: the slave/reader achieving selfconsciousness by opposing the master/author. But Mallarmé does not always rush towards a dialectic reversal. In the passage under consideration, it is hard to detect any such urgency; in fact, with his 'ne s'y arrêter', Mallarmé sidelines the question of who does what. Secondly, and as a consequence of this, Barthes's reading appears too anthropocentric. In his autobiographical letter to Verlaine, Mallarmé notes that the 'le rythme' should be 'impersonnel et vivant' (OC1: 788), and in L'Action restreinte he goes on to write: 'Impersonnifié, le volume, autant qu'on s'en sépare comme auteur, ne réclame approche de lecteur' (OC2: 217). As Jacques Rancière remarks, this obviously does not mean that the book should not be read. ${ }^{20}$ It rather means that even before it is taken up by a reader (as it eventually should be), the book is a site for 'des relations entre tout'. Mallarmé's work is full of such speculative statements that critics have either left untouched or used to build the image of an idealist Mallarmé. For instance, the 1876 text on Manet is also more complicated than a simple switch from artist to spectator: nature complicates things. Here, Mallarmé writes that nature recruits artists to work for her, so that she can express herself to - and through - the new democratic citizens:

\footnotetext{
${ }^{18}$ Roland Barthes, Le Bruissement de la langue (Paris: Éditions du Seuil, 1984), pp. 64-65. ${ }^{19}$ Ibid., p. 69.

${ }^{20}$ Jacques Rancière, Mallarmé: La Politique de la sirène (Paris: Hachette, 1996), p. 66.
} 
At that critical hour for the human race when natures [sic] desires to work for herself, she requires certain lovers of hers - new impersonal men placed directly in communion with the sentiment of their time - to loose the restraint of education, to let hand and eye do what they will, and thus through them, reveal herself (OC2 468, emphasis added).

Whereas Barthes's famous formulations suggest an opposition between author and reader (and its dialectic resolution), Mallarmé troubles this anthropocentric framework by presenting the book as both place and event. Mallarmé is concerned with what we might call 'the bookevent', with how 'entre les accessoires humains, il [le livre] a lieu, tout seul: fait, étant' (OC2: 217). The 'avoir lieu' is to be understood in a very active sense, closer to the English take place. Mallarmé is interested in how 'l'œuvre esthétique fait bourgeonner l'univers', ${ }^{21}$ as Simondon puts it in the second epigraph to this article: how the world can express itself through the book, and eventually (remembering that the 'relations entre tout' include humans too), how this book can also stimulate and influence writers and readers. In these years of 'thing-power' 22 and a widespread and generally justified critique of anthropocentrism, this emphasis on the book as place and event is important and will be discussed substantially in my third section. However, this does not mean that Mallarmé entirely eliminates the author. The topological and active nature of the book still relates to what Mallarmé called the task ('le devoir') of the writer in Sauvegarde. As we saw, '[1]e devoir de maintenir le livre

\footnotetext{
${ }^{21}$ Simondon, Du mode d'existence des objets techniques, p. 254.

${ }^{22}$ See Jane Bennett, Vibrant Matter: A Political Ecology of Things (Durham, NC: Duke University Press, 2010).
} 
s'impose, en l'intégrité', because this allows fiction to inform the ever ongoing creation of the social bond.

Again, a counter-example might help to clarify. We know from Mallarmé's work that places do not always take place. For instance, Mallarmé was not sure that Paris 1895 was taking place. He wrote about his time-place being (in) a tunnel, and he explained that in this (non-)situation, it was impossible to be contemporary to oneself: 'Il n'est pas de Présent, non — un présent n'existe pas.. Faute que se déclare la Foule, faute — de tout. Mal informé celui qui se crierait son propre contemporain' (OC2: 217). By contrast, the book can take place, and it can allow its readers to take place too: 'la poésie [...] doue ainsi d'authenticité notre séjour' $(O C 2: 782)$. The poet's task is to make sure that this happens.

With this short intertextual reading of the first two paragraphs in Le Livre, instrument spirituel, I have attempted to map the relations between three strands in Mallarmé's thinking about the book. First, that the book comes with a socio-political dimension, offering itself as a model for the social bond, the writing of which must be open-ended and collective. Second, that beauty plays a key role in the attainment of this social status. Beauty 'proves' that the book is working for the collective. It ensures that the artwork takes place, reaching beyond the private realm to a common sphere. Finally, I have considered the question of agency, in what is still a non-conclusive way. Clearly, Mallarmé minimizes his claim to authorship, leaving the initiative to readers and presenting the book as a collectively produced phenomenon. But we have also seen that the book is given a form of agency which exceeds the human perspective: it takes place by itself, communicating with the night sky. In order to further explore this question of agency, it is necessary to examine the issue of instrumentality: how do we interact with the book? What is the practice of the book? 


\section{The Book as Practice}

As the term 'instrument' suggests, there is a hands-on aspect to Mallarmé's proposition about the book taking place, the world becoming book. This I will call 'the book as practice', and 'practice' will be understood in the sense that Isabelle Stengers gives it (drawing on A. N. Whitehead), when she proposes that practice is a matter of 'giving to the situation the power to make us think and feel' ${ }^{23} \mathrm{We}$ can already see that this definition resonates with Mallarmé's writings on the book insofar as it distributes agency evenly between the practitioner and the situation, inviting us to abandon the anthropocentric perspective.

The word 'pratique' appears on several occasions in Mallarmé's works, not least when he is considering the reading process. In Le Mystère dans les lettres (1896), defending himself against Proust's critique in 'Contre l'obscurité', ${ }^{24}$ Mallarmé writes:

Lire -

Cette pratique -

Appuyer, selon la page, au blanc, qui l'inaugure son ingénuité, à soi, oublieuse même du, titre qui parlerait trop haut: et, quand s'aligna, dans une brisure, la moindre, disséminée, le hasard vaincu mot par mot, indéfectiblement le blanc revient, tout à l'heure gratuit, certain maintenant, pour conclure que rien au-delà et authentiquer le silence - (OC2: 234).

${ }^{23}$ Isabelle Stengers, 'Introductory Notes on an Ecology of Practices', Cultural Studies, 11.1 (2005), 183-196 (p. 185).

${ }^{24}$ See Marcel Proust, 'Contre l'obscurité', La Revue blanche, 11.2 (1896), 69-72. 
Here, the practice of reading is characterized as a movement from white to white, from silence to silence. Throughout this journey, the initial 'blanc' or silence - the white paper that precedes the title, or the silence that precedes a reading - undergoes a transformation and is replaced by a meaningful white (or silence). The 'mystère' of the title has found expression, and we are able to see more clearly the relations between various aspects of the universe. In this particular passage, Mallarmé no longer writes about mapping the 'relations entre tout', but his well-known idea about overcoming chance expresses the same thought, and in the next paragraph culminates in the harmonious image of the 'preuves nuptiales de l'Idée' (OC2: 234), reinstating the idea of proof.

We can note how the mechanics of reading are conveyed. Mallarmé recommends a step-by-step (or word-by-word) procedure for the overcoming of chance. Through this process, the task of reassembling - and finding a place in - the universe is accomplished. In order to make this reading-practice palpable, Mallarmé is simultaneously literal and abstract: 'appuyer' might refer to the finger pressing on the page, following the sentence as it unfolds; he writes about paper, title, words and spaces, and in the next sentence introduces the more technical terms 'fleuron' and the 'cul-de-lampe'. This is at the same time pragmatic and wildly idealist.

As mentioned, Mallarmé minimizes the difference between the activity of the writer and that of the reader. It is therefore not surprising that another famous text about the practice of writing from 1896, L'Action restreinte, resonates very strongly with the passage that we just considered: 
L'encrier, cristal comme une conscience, avec sa goutte, au fond, de ténèbres relative à ce que quelque chose soit: puis, écarte la lampe.

Tu remarquas, on n'écrit pas, lumineusement, sur champ obscur, l'alphabet des astres, seul, ainsi s'indique, ébauché ou interrompu; l'homme poursuit noir sur blanc (OC2: 215).

Here, we find the same layout on the page (isolating the key verb, performatively surrounding it with 'blancs'), the same interplay between black and white, the same striving for light, and the same combination of the concrete ('l'encrier de cristal', 'la goutte d'encre', 'la lampe') and the metaphysical. The passage from Le Mystère dans les lettres linked reading to the possibility of overcoming chance; this second passage similarly suggests a cosmic architectonics relying on the communication between page and sky, letters and stars. The passage thereby points to numerous other famous pages in Mallarmé's works, not least the penultimate key sentence in Un coup de dés - 'RIEN [...] N'AURA EU LIEU [...] QUE LE LIEU [...] EXCEPTÉ [...] PEUT-ÊTRE [...] UNE CONSTELLATION' (OC1: 384-87) - where the mirroring of place, page and sky becomes so intricate that 'constellation' demands to be taken both in its astronomical sense and as a reference to the layout of the text. In both practices (reading and writing), the physical and the metaphysical become indistinguishable: it is via the practice of reading, writing, going step by step, while paying attention to the black and the white on the page and in the sky, that Mallarmé and his reader close the gap between book and world.

Finally, La Musique et les lettres presents a third - perhaps the most famous expression of this idea of writing and reading as a creative, step-by-step mapping and 
harmonization of the structures of the world. Now, the practice is no longer tied to either reading or writing, it is simply creative:

La Nature a lieu, on n’y ajoutera pas; que des cités, les voies ferrées et plusieurs inventions formant notre matériel.

Tout l'acte disponible, à jamais et seulement, reste de saisir les rapports, entre temps, rares ou multipliés; d'après quelque état intérieur et que l'on veuille à son gré étendre, simplifier le monde.

À l'égal de créer: la notion d'un objet, échappant, qui fait défaut.

Semblable occupation suffit, comparer les aspects et leur nombre tel qu'il frôle notre négligence: y éveillant, pour décor, l'ambiguïté de quelques figures belles, aux intersections. La totale arabesque, qui les relie, a de vertigineuses sautes en un effroi que reconnue; et d'anxieux accords (OC2: 67-68).

Mallarmé begins with a realist axiom, insisting that Nature takes place. This axiom resonates with what the preceding paragraph called a 'formule absolue': 'n'est que ce qui est' (OC2: 67), and with the 'rien au-delà' (OC2: 234) we encountered in Le Mystère dans les lettres. Next, he explains how we can come to terms with reality by an act of capture ('saisir les rapports') through which we calibrate this outside world according to ourselves ('d'après quelque état intérieur'). Mallarmé presents this activity as a creative act that transcends us ('créer: la notion d'un objet, échappant'). ${ }^{25}$ Finally, the last paragraph gives a clear sense of

\footnotetext{
${ }^{25}$ Again, Mallarmé is returning to ideas presented in the previous paragraph, where he celebrated our capacity to invent fictions that transcend our own understanding: "je vénère comment, par une supercherie, on projette, à quelque élévation défendue et de foudre! le conscient manque chez nous de ce qui là-haut éclate' (OC2 67).
} 
the complexity of this creative practice: we must search for nodal points between the internal and external universe, for the complex and beautiful 'figures', the sudden leaps - in order to establish the overall pattern: 'la totale arabesque'.

Throughout the paragraph, Mallarmé describes this creative entanglement in the world with metaphors that draw heavily upon the arts ('décor', 'accords') and often cut across various artistic forms: 'arabesque' and 'figures', for instance, are terms from the worlds of music, linguistics, ballet and the visual arts. It is therefore possible to hear echoes both of Mallarmé's descriptions of dance performances by Loïe Fuller and others, and of typical mallarméan metaphors for the artistic process: constellations, fireworks, lacework, and the idea of the poet as a spider, spinning complex webs. The task is to map the universe, and mapping is a creative act that allows the mapmaker to engage intimately with the world, blurring relations between inner and outer in order to achieve a form of equilibrium which Mallarmé describes as a simplification of the world ('simplifier le monde’).

Many other texts could allow us to further set out Mallarmé's assemblage - his DIY aesthetic. Somewhat like musical scores, his poems require a careful, creative appropriation; and in both his poetry and prose, syntax plays a key role in this step-by-step assemblage. However, to concretize further, let us now turn to one of the most hands-on expressions of his creativity: the playful and meticulously crafted reading machines he produced for the students in his English classes at the Lycée Condorcet.

L'Anglais récréatif (displayed at the Musée Valvins in a 2014 exhibition) is a small, brochure-like project focusing on twelve different aspects of the English language. ${ }^{26}$ Page ten, for instance, is dedicated to the learning of prepositions. Mallarmé has drawn a beautiful flower on a small stand. A piece of string connects the centre of the flower to a hand-painted

\footnotetext{
${ }^{26}$ See Bertrand Marchal and Marie-Pierre Pouly, Mallarmé et l'anglais récréatif: le poète pédagogue (Paris: Cohen \& Cohen, 2014).
} 
piece of cardboard shaped like a butterfly. On the page, we find a series of prepositions in French and English, according to which the butterfly can be moved. It can for instance be placed 'over' the flower or 'below' it; it can remain 'far' from the flower or go 'into' it. It is easy to imagine the exercises one could perform with this page - one might even allow the students to invent games of their own.

Other pages in L'Anglais récréatif have pull systems, strings, or loose pieces that can be used to cover sections of the page (as in a game of bingo). Via small movements and interactions with the page, Mallarmé clearly hopes that his students will play their way to an understanding of English numbers, verb structures, adjectives, and so on. The wider conclusions that can be drawn from this pedagogical work have to do with the invention of new reading practices. As Arnar suggests, Mallarmé leaves behind linearity and points towards the more spatially complex reading practice that is required for Un coup de dés, and for the many poems and prose texts in which he plays with syntax. ${ }^{27} \mathrm{We}$ can also note how the various ways of animating the page, the complex relations between text and colour images, and the layering and superimpositions resonate with nascent media forms such as cinema. ${ }^{28}$ However, the key point is that L'Anglais récréatif brings together ideas about the book, instruments, play and enlightenment. The project thereby reminds us of the etymological link between instruments and instruction: 'instrument' comes from the Latin instruere, 'to build upon, assemble'. This etymology links to ideas of education as an activity of formation, a step-by-step practice which aims at enlightenment. As we have already seen, this is precisely what reading and writing was for Mallarmé, not least if we push this process to the point where education is no longer simply a question of forming and enlightening

\footnotetext{
${ }^{27}$ Arnar, The Book as Instrument, p. 165.

${ }^{28}$ See Christophe Wall-Romana, Cinepoetry: Imaginary Cinemas in French Poetry (New York: Fordham University Press, 2013).
} 
individual human beings, but also a less anthropocentric endeavor which allows ideas to manifest themselves in the universe: 'les preuves nuptiales de l'Idée', as Mallarmé put it. In this manner, the pedagogical book becomes a small-scale example of the book-event.

Mallarmé's system of reverberations between man, page and sky makes it very difficult to say exactly who does what. To further explore this issue of distributed agency, I will now turn to the writings of Gilbert Simondon. There are three good reasons for introducing Simondon: he theorizes instruments (or rather, technical objects ${ }^{29}$ ) in a manner that will put the 'spiritual instrument' in a new light; his philosophy of individuation allows us to take another look at the issue of agency, and unearth the understanding of subjectformation that sustains Mallarmé's writings; and finally Simondon has emerged as one of the key thinkers of our times, and therefore provides us with an entry point to the discussion of Mallarmé's significance today.

\section{The Production of the Individu-Livre}

Let us begin with the notion of the technical object. In an interview from 1965, Simondon explains that he introduced this notion (featured in the title of his 1958 dissertation $D u$ mode d'existence des objets techniques) in the hope that it would resonate with the more wellknown terms 'objets esthétiques' and 'objets sacrés'. ${ }^{30}$ This move indicates that he sees technical objects as far more than utilitarian, and that he is keen to place them in relation to art and religion (thereby establishing the same triangular relation we find in Mallarmé's title

${ }^{29}$ Simondon has a much more fine-grained vocabulary for instruments, machines and technical objects (open and closed) than Mallarmé. I am unable to present these differences in here. See Gilbert Simondon, L'Invention dans les techniques: cours et conférences (Paris: Éditions du Seuil, 2005).

${ }^{30}$ Gilbert Simondon, Sur la technique (Paris: Presses universitaires de France, 2014), p. 400. 
Le Livre, instrument spirituel). Part of the relation to art has to do with technical objects being invented, and therefore, Simondon insists, containing a human element. ${ }^{31}$ Many scholars in the humanities forget this human dimension of the technical, and Du mode d'existence des objets techniques therefore opens with a polemic against the 'facile humanisme' that has built itself in opposition to technical reality: 'Nous voudrions montrer que la culture ignore dans la réalité technique une réalité humaine, et que, pour jouer son rôle complet, la culture doit incorporer les êtres techniques sous forme de connaissance et de sens des valeurs'. ${ }^{32}$ Fundamentally, 'l'opposition dressée entre la culture et la technique, entre l'homme et la machine, est fausse et sans fondement; elle ne recouvre qu'ignorance ou ressentiment' 33

Even if the idea of the 'objet technique' is useful for drawing technics closer to the sacred and the aesthetic, the idea of the 'object' is also misleading. Simondon is more interested in technics as a process, a life form, a matter of evolution. A cornerstone in his thinking is that man and technics interact in ways that allow both parties - and their shared environments - to co-evolve. In the slightly later text on Culture et technique (1965), he therefore describes technics as an activity through which we become entangled in the world:

Il ne s'agit donc plus ici d'une technique comme moyen, mais plutôt comme acte, comme phase d'une activité de relation entre l'homme et son milieu; au cours de cette

${ }^{31}$ In these years of 'the nonhuman turn' where so many cultural critics are drawing on Simondon, it is worth saying that he has no ambition to be nonhuman. His ontology may be non-anthropocentric (he looks at life forms that are nonorganic, biological and technical), but he never seeks to escape the human being.

${ }^{32}$ Simondon, Du mode d'existence des objets techniques, p. 9.

${ }^{33}$ Simondon, Du mode d'existence des objets techniques, p. 9. 
phase, l'homme stimule son milieu en introduisant en lui une modification; cette modification se développe, et le milieu modifié propose à l'homme un nouveau champ d'action, exigeant une nouvelle adaptation, suscitant de nouveaux besoins; l'énergie du geste technique, ayant cheminé dans le milieu, revient sur l'homme et lui permet de se modifier, d'évoluer. ${ }^{34}$

This passage can also be said to elucidate Mallarmé's idea of the book as spiritual instrument. In both cases, the technical object (or book) facilitates a practice that mediates between man and universe in 'une activité de relation', as Simondon put it. The interplay between man, technical object/book and universe is dynamic: all three components are modified in this process, all three are implicated in a process of co-evolution.

In the third and most speculative part of Du mode d'existence des objets techniques, the philosopher probes this relation between art, technics and religion even further. Breaking with the sober approach used throughout his text, he tells a story about the development of human culture. This story begins in a magical universe where man and world were in direct communication. Simondon writes about 'la première structure de l'univers, à savoir la réticulation des points-clefs, médiation directe entre l'homme et le monde' ${ }^{35}$ Eventually, this magic universe split into a religious universe and what he calls a 'closed' technical universe, and the risk now is that the original structure will remain forever lost. ${ }^{36}$ This is where art steps in:

\footnotetext{
${ }^{34}$ Simondon, Sur la technique, p. 320.

${ }^{35}$ Simondon, Du mode d'existence des objets techniques, p. 251.

${ }^{36}$ Simondon's focus on technical processes does not mean that he overlooks how instruments and machines can produce alienation and reification. He distinguishes between 'open' and 'closed' technical objects, the first being processual and allowing a mediation between man
} 
Or, l'activité esthétique préserve précisément cette structure de réticulation. Elle ne peut la préserver réellement dans le monde, puisqu'elle ne peut se substituer aux techniques et à la religion, ce qui serait recréer la magie. Mais elle la préserve en construisant un monde dans lequel elle peut continuer à exister, et qui est à la fois technique et religieux; il est technique parce qu'il est construit au lieu d'être naturel [...] ; il est religieux en ce sens que ce monde incorpore les forces, les qualités, les caractères de fond que les techniques laissent de côté [...], la pensée esthétique, [...] fait ainsi la réalité esthétique, nouvelle médiation entre l'homme et le monde, monde intermédiaire entre l'homme et le monde. ${ }^{37}$

This passage presents the contours of what we might call the aesthetic rescue operation of the intimate relation between man and universe. Despite the potentially nostalgic ring to the passage, Simondon has no illusions about how the magical unity between man and universe could return in reality. Instead, the passage makes clear that art offers a way of bringing the religious and the technical together in a work of fiction. Art is technical, it is constructed or invented, it relies on craft. But art is also religious insofar as it addresses and relates to those fundamental experiences ('les forces, les qualités, les caractères de fond') that closed technologies cannot reach. In this manner, artworks draw on technics and religion to reinvent a relation to foundational elements, creating a fiction-assemblage situated between man and world. Art becomes a mediating event - neither subjective, nor objective, but rather, as with Mallarmé's ambition to 'saisir les rapports', an ecological practice.

and environment, the second being non-processual, utilitarian and separating man from world. See, for instance, Simondon, Sur la technique, pp. 319-22.

${ }^{37}$ Ibid., pp. 251-252. 
The correlation between the Mallarmé's 'instrument spirituel' and Simondon's analysis of our interaction with (aesthetic, technical and sacred) instruments relies on a fundamental overlap between their views on subjectivity. To fully harvest the potential of this parallel reading between Mallarmé and Simondon, we must therefore briefly consider Simondon's philosophy of individuation. In L'Individuation à la lumière des notions de forme et d'information, Simondon suggests that if we want to understand what an individual is, we should not do what Western philosophers have generally done: we should not begin by considering the individual. If we begin with the individual and then try to establish its relation to other individuals and the world more widely, we will be stuck in a dualist ontology of subjects and objects. Simondon's non-dualist ontology, on the other hand, begins with the various processes of individuation that play out in what he calls a 'preindividual' situation, thereby preceding the individual human being. Eventually these processes come together to form an 'individu-milieu' (Simondon compares the shaping of the individu-milieu with a process of crystallisation). Individuals should be viewed as temporary and partial mediations of the preindividual situation, who then play their part in future processes of individuation. In this manner we move from 'an ontology of being to an ontology of becoming'; 38 from 'beings as things to being as event'. 39

When Mallarmé engages with the place and instrument he calls 'le Livre', we witness an exchange between universe, book and writer/reader that brings to mind Simondon's

${ }^{38}$ Anne Sauvagnargues, 'Crystals and Membranes: Individuation and Temporality', in Gilbert Simondon: Being and Technology, ed. by Arne de Boever and others (Edinburgh: Edinburgh University Press, 2012), pp. 57-70 (p. 58).

${ }^{39}$ Miguel de Beistegui, 'Science and Ontology: From Merleau-Ponty's "Reduction" to Simondon's “Transduction”", in Gilbert Simondon: Being and Technology, ed. by Arne de Boever and others (Edinburgh: Edinburgh University Press, 2012), pp. 154-175 (p. 168). 
writings on technicity and individuation. In this exchange, the individual (whether reader or writer) takes part in a creative practice of mapping, and through this process understands itself as part of an environment. Borrowing from Simondon's ideas about the 'individumilieu', we can call this the production of the 'individu-livre'. For this individu-livre, action reading and writing, for instance - is conceived as taking part in a process of 'réticulation': it is about establishing 'des relations entre tout' in view of creating a book-event, and it is about how we ourselves are integral to that process (like a spider making a web). Beauty is the yardstick for this event, because it turns the event towards the public.

On this basis, we can reconsider the complex question of agency. Earlier, we asked: who does the recruiting when man is 'chargé de voir divinement'? Does the initiative lie with the book, the writer, Nature, language or the reader? As we saw, Roland Barthes famously answered that Mallarmé's poetics consists in overthrowing the author in order to empower the reader. ${ }^{40}$ Famous passages from Mallarmé's writing corrobate this reading, but we also found passages that describe how Nature recruits 'certain lovers of hers...', and how 'the book' takes place by itself. My view is not that Mallarmé is changing his mind, contradicting himself. Rather, the point is that the spiritual instrument cannot be captured in the subjectobject relations that questions of agency frequently presuppose; that Mallarmé is difficult to contain within a dialectical, anthropocentric framework. The logic of emergence that Mallarmé associates with the 'Livre' is one of co-emergence. Instead of trying to untangle the issue of agency, it seems more appropriate to say that the book takes place in and as a constellation, it modulates readers, writers and their associated milieus, and is itself modulated in that process. It is these movements that Mallarmé terms 'spirituel[s]'.

\footnotetext{
${ }^{40}$ Some critics may object that Barthes can be read in a nonanthropocentric way, that 'the text' supersedes the dialectic between authors and readers. This point becomes increasingly valid as one considers the texts Barthes wrote towards the end of his life.
} 
Mallarmé is thus a poet with a radically ecological conception of individuation. This is one of the ways in which his poetry resonates with twenty-first-century thought: with theories about our anthropocene condition, and with philosophies about our technologically mediated processes of individuation. He understands the human being as profoundly caught up in the structures of the world, and the book as an instrument both for understanding this condition, and for navigating it. Mallarmé's key metaphors (constellations, fireworks, spiderwebs, lacework, etc.) all highlight the relational nature of poetic work. This is why he so frequently writes about 'relations' and 'rapports'; and when he insists on the importance of syntax - 'il faut une garantie — La Syntaxe —' $(\text { OC2: 232-233 })^{41}$ - this Greek word must similarly be understood in its etymological sense of arranging, combining, composing. Mallarmé's emphasis on the relational work of the poet is so strong that when an 1893 letter to Edmund Gosse presents the etymology of another Greek keyword ('Musique') he brings it surprisingly close to 'syntaxe': 'Employez Musique dans le sens grec, au fond signifiant Idée ou rythme entre des rapports'. ${ }^{42}$ With all these metaphors and concepts, Mallarmé is looking to link up, to weigh up, to tune, and to modulate; not to invent ex nihilo.

Many scholars worry about the process-relational conceptions of individuation that we find in the work of philosophers like Whitehead and Simondon, and that I have here associated with Mallarmé. They worry that if we understand ourselves as modulators who are being modulated as we modulate, we somehow lose individual human agency. But these

${ }^{41}$ Mallarmé introduces a double line-break before and after 'La Syntaxe — ', visually communicating that syntax plays a pivotal role (the word 'pivot' is in Mallarmé's text). ${ }^{42}$ Stéphane Mallarmé, Correspondance complète 1862-1871 suivi de Lettres sur la poésie 1972-1898. (Paris: Gallimard, 1995), p. 614. A more conventional etymology would note that 'musique' refers to the art of the muses (and that the word 'muse' is linked to literary art in particular). 
ideas about our embeddedness in the world do not rob human beings of agency, or responsibility. Quite the contrary. As N. Katherine Hayles points out in her recent book on how certain forms of cognition are shared by humans and their technological inventions, it remains true that:

the largest transformative forces on the planet today are undoubtedly human agency and human interventions, the effects of which are being registered in climate change, the worldwide loss of habitat for nonhuman animals, the idea of the Anthropocene, and in the reality that human actions are unleashing forces far beyond our ability to control them. ${ }^{43}$

In this situation we must search for 'inflection points at which systemic dynamics can be decisively transformed'. ${ }^{44}$ In other words, the (generally collective) modulations that the process-relational thinkers theorize aim for a high impact.

When it comes to the interpretation of Mallarmé's writings however, the question of which notion of agency the contemporary critic desires is obviously not the place to begin. Here it is better to ask: does Mallarmé distribute agency liberally across book-instruments, readers, writers, nature and language? Does he present individuation as a radically ecological practice? Is the Individu-Livre an appropriate way to describe the figure emerging from the poetic lacework? I have argued that Mallarmé's conceptualization of the book as spiritual instrument guides us to an affirmative answer to all of these questions, and that his imagination is therefore at once more wildly idealist and more practically bricoleur than is

\footnotetext{
${ }^{43}$ N. Katherine Hayles, Unthought: The Power of the Cognitive Nonconscious (Chicago: Chicago University Press, 2017), p. 83.

${ }^{44}$ Ibid., p. 203.
} 
often assumed. For Mallarmé, instrumentality has no necessary link to reification and objectification; on the contrary, the practice of (or play with) the instrumental, spiritual book results in an Individu-Livre that can still inspire readers as we advance into the twenty-first century. Mallarmé is exploring key contemporary questions about what it means to be an environment, which forms of individuation are facilitated by our different instruments, and how an 'action restreinte' may help produce new constellations. 